e-ISSN: 2721-3013, p-ISSN: 2721-3005

DOI: https://doi.org/10.38035/jafm.v1i1

Received: 06 February 2020, Revised: 18 Ferbruary, Publish: 3 March 2020

https://creativecommons.org/licenses/by/4.0/

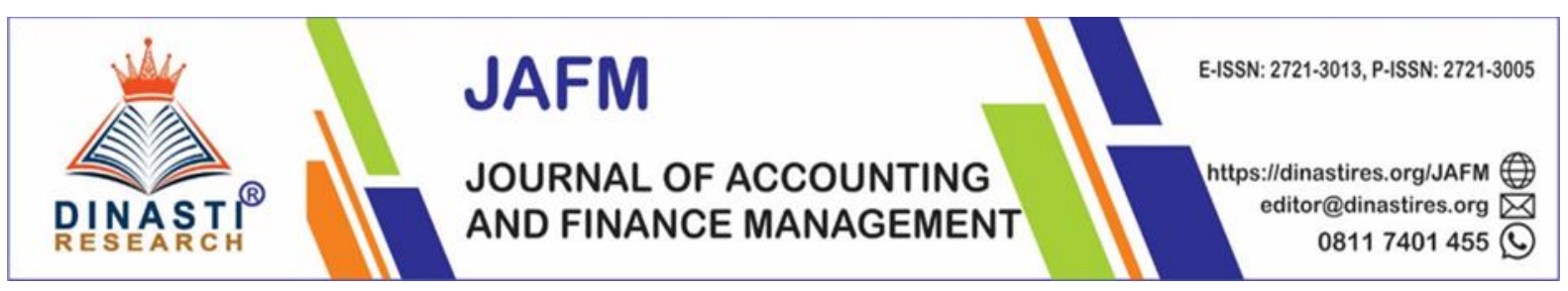

\title{
The Effect of Work Climate and Leader Traits on Teacher Job Satisfaction Jambi City State High School
}

\section{Firman}

Universitas Jambi, Indonesia, email: firman.fkip@unja.ac.id

Corresponding Author: Firman

\begin{abstract}
The purpose of this study is to examine the direct influence of the work climate and the characteristics of leaders on job satisfaction of teachers in Jambi City Public High School. This study uses a quantitative approach with the research subjects of SMA Negeri 1 Jambi City, SMA Negeri 3, SMAN Negeri 4, and SMA Negeri 5 Jambi City with a sample of 63 students. The instrument used for data collection in the form of a list of questions or questionnaire. Data collected from respondents were then processed using path analysis. Before carrying out statistical analysis, the data must meet the requirements of the analysis prerequisite tests that will be used. The tests were the normality test, linearity test, homogeneity test. The results showed that the work climate had a significant effect on job satisfaction in the amount of $12.2 \%$ with a significance level of 0.005 . The nature of leadership has a significant effect on job satisfaction in the amount of $10.3 \%$ with a significance level of 0.009 . If teacher job satisfaction reaches a percentage level of $100 \%$, then $10.3 \%$ is contributed by the nature of leadership. Work climate and leadership characteristics have a significant effect on job satisfaction in the amount of $14.4 \%$ with a significance level of 0.009 . If teacher job satisfaction reaches a percentage level of $100 \%$, then $14.4 \%$ is contributed by the work climate and the nature of leadership.
\end{abstract}

Keywords: Work Climate, Leader Characteristics, Teacher Job Satisfaction

\section{INTRODUCTION}

Job satisfaction is an individual. Each individual has a different level of satisfaction by the value system that applies to him/her. The higher the assessment of the activity felt by individual desires, the higher the satisfaction with the activity itself. Thus, satisfaction is an evaluation that describes a person's feelings, happy or not happy feelings, satisfied or not satisfied at work. (Rivai, 2013:856)

The problem of job satisfaction does not only occur in corporate organisations or governments. However, it can also occur in educational units or schools. Education is a very strategic process in the intellectual life of the nation, so it must be done professionally. Therefore, the teachers, as one of the educational practitioners, must be a professional. Thus, 
the presence of teachers in the education process can be meaningful for students, the community, and the nation and leads to a better appreciation for teachers.

The working climate also influences an organisation because it has a different work climate, the diversity of jobs designed within the organisation, or the nature of the individuals that exist will reflect these differences. All organisations naturally have a strategy in managing human resources. An open organisational climate encourages teachers to express their interests and dissatisfaction without fear of retaliation and attention. In a pleasant working climate, teachers are expected to be able to participate in national development. Achieve the devoted to God Almighty society, excel in science and technology, have an aesthetic, ethical spirit, virtuous character and personality. It is no exaggeration to say that the future of society, nation and state is mainly relying on the teachers. Therefore, the teaching profession needs to be developed thoughtfully and proportionally according to the functional position of the teacher.

The nature of leadership also influences job satisfaction. A leader is someone who can influence others and have managerial authority. Terry and Rue as quoted by Usman define that leadership is the relationship that exists in a leader, influencing others to work together consciously in the desired task relationship (Husain, 2011:280)

Meanwhile, leadership is the process of leading a group and influencing the group in achieving its goals. Thus, leadership plays a vital role in management. In reality, not all people who occupy leadership positions have the ability to lead or have leadership. Conversely, many people have leadership talents but never get the opportunity to become a leader in the real sense.

Based on the results of observation made at Jambi Province LPMP, 575 educators were obtained in Jambi City who were teachers. From the work period, the class and average salary received can be seen in the table below.

Table 1. Number of teachers, tenure, average salary, and a class of certified teachers in Jambi Province Public High School

\begin{tabular}{lccccccc}
\hline \multirow{2}{*}{ Region/City } & No. Of & \multicolumn{2}{c}{ Tenure } & \multicolumn{2}{c}{ Class } & \multicolumn{2}{c}{ Average Salary (Rp) } \\
\cline { 3 - 7 } teachers & III & IV & III & IV & III & IV \\
\hline \multirow{2}{*}{ Jambi City } & 575 & $\begin{array}{c}10-19 \\
\text { years }\end{array}$ & $\begin{array}{c}20-30 \\
\text { years }\end{array}$ & 183 & 392 & 5.235 .000 & 7.510 .000 \\
\hline
\end{tabular}

Source: LPMP Jambi Province 2014

Based on the table above, it can be seen that teacher job satisfaction in salary or wages is sufficient. The average salary of a teacher who is in class III certification is Rp. 5,235,000 and group IV is Rp. 7,510,000, not including food allowance.

However, based on the results of preliminary observations, it was still found that most of the teaching staff in Jambi province felt dissatisfaction with their work. In the interview, one of the teachers said that "... in carrying out the work as a teacher, our task is no longer free and there is a tendency of the pressure from the leader. Graduation and promotion of students are some of the examples. Some children should not have gone to the higher grade, but the leader asked to increase and change the report from the actual grades. In another interview with different teachers about the work environment, they said that ". in carrying out the work there is no exact word in applying the rule between teachers.

In this case, an effective leader is a person who gives and takes effective direction for the organisations-those who are led and pay attention to healthy and productive performance in the workplace. The nature of one's leadership is one's ability to make others willing to follow him/her. Any organisations must work effectively. Therefore, a leader must learn how to be an effective leader.

If job satisfaction and the factors that influence it, such as the qualities of a leader can 
be identified through this research, the results of this study will be useful as part of selfevaluation. Therefore, some steps can be determined to maintain job satisfaction in the work environment of the education unit.

Based on the description above, the author intended to research the title "The Effect of Work Climate and Leaders' Traits on Job Satisfaction of Teachers in Jambi City High School".

\section{LITERATURE REVIEW Work Climate}

Gibson and Donnelly suggest that work climate is a series of work climate conditions that are felt directly or indirectly by workers. It is one of the forces that influence worker behaviour. Work climate is an atmosphere that is created by the pattern of the relationship between personal work. (Djoerban, 20017:702).

John argues that the work climate is determined by the social relations of the people in the work climate, and the reward system is used to motivate workers. The definition of social relations here is a broad understanding. It includes both vertical and horizontal communication, cooperation between workers, supervision from superiors, support from subordinates, and clarity of duties carried out by each worker. Salunke explains that the work climate refers to the relationship between workers and the environment. It can be broken down into different dimensions such as social, technical and economic, where the work is usually seen and designed. (Ganesh, 2015:22).

\section{Leader Traits}

Most definitions of leadership reflect the assumption that leadership is related to the deliberate process of a person to emphasise his/her strong influence on others. The influences include to guide, structure, facilitate activities and relationships within a group or organisation. Gary Yulk mentions five approaches in leaders, namely:

1. The individual approach

2. The behavioural approach

3. The power-influence approach

4. Situational approach

5. The integrative approach

(Gary, 2007:3). Furthermore, seen in modern leader theory, there are for approach, namely: (1) trait theory, (2) human relations, (3) behaviour, (4) contingency and situational.

The trait approach argues that leaders are born, not created, meaning that someone has brought the talent of leaders from birth, not educated or trained. Leaders who are born without going through education and training can become effective leaders. Leader training is only useful for those who already possess the qualities of a leader. That is, someone who does not have the qualities and talents of leaders who are brought from birth, do not need to be trained because it will be in vain. Northouse explains that the natural approach has aroused interest because it explains how nature influences leadership. (Peter, 2013: 19).

\section{Job Satisfaction}

Job satisfaction refers to the attitudes commonly shown by employees towards their work. Although job satisfaction tends to refer to attitudes rather than behaviour, this is a result that managers often observe. It is because satisfied employees tend to be more often present in the office, have high work performance, and are loyal to the organisations. Stephen defines job satisfaction as an individual's general attitude towards his/her job. (Stephen, 2016: 13).

Job satisfaction is also part of employees' perceptions that expectations are exceeded or 
fulfilled. If an employee who carries out an activity, then the benefits needed will be by what he/she expected, then he/she will feel satisfied, and vice versa. Rivai and Mulyadi argue that job satisfaction is an assessment of workers about how far their work overall satisfies their needs. Job satisfaction is also a general attitude which is the results of several specific attitudes towards work factors, adjustments and social relations of individuals outside of work. (Veithzal and Mulyadi, 2013: 246).

Workers who are satisfied with their work tend to be productive even though the relationship between job satisfaction and performance shows a smaller positive relationship. In the theory of expectations, there are three major concepts, namely:

1. Performance outcome expectations, where each individual who performs specific actions, will expect results of his/her actions.

2. Valence, which is a measure of the strength of one's desires for positive results.

3. Effort-performance expectancy, which is the hope for success, determines the satisfaction of the behaviour to be performed.

Falkenburg and Schyns, as quoted by Suki, explained that job satisfaction could be seen as a result of the behavioural cycle. It can also be the cause of the behaviour, can be seen as a part of the regulatory system- where the evaluation of results leads to a decision regarding whether or not changes must be made. (Norazah, 2011: 1).

\section{RESEARCH METHOD}

This study uses a quantitative approach, which is a research method based on the philosophy of positivism, used to examine populations or specifics samples. Sampling techniques are generally carried out randomly, data collection using research instruments, quantitative/statistical data analysis to test the hypothesis which has been set.

The population in this study were all high school teachers in Jambi Province. The target population and the affordable population that were made as the target of the study were Jambi City Senior High School teachers taken by random sampling. They were SMA Negeri 1, SMA Negeri 3, SMA Negeri 4 and SMA Negeri 5, which are summarised in the following table.

Tabel 1. Number of Teachers in Jambi City Public High Schools by 2014 Employee

\begin{tabular}{clc}
\hline No & \multicolumn{1}{c}{ Schools } & Civil Servants \\
\hline 1 & SMA Negeri 1 Jambi City & 41 \\
\hline 2 & SMA Negeri 3 Jambi City & 46 \\
\hline 3 & SMA Negeri 4 Jambi City & 39 \\
\hline 4 & SMA Negeri 5 Jambi City & 45 \\
\hline & Total & $\mathbf{1 7 1}$ \\
\hline
\end{tabular}

Source: LPMP Jambi Province

Based on the formula above, the total sample size is 63.09 and rounded up to 63 people. For this reason, a large number of samples from each region must be generalised, which can be seen in Table 3.2 below:

Table 2. Total Sample

\begin{tabular}{cccc}
\hline No. & Regency & Population & Sample \\
\hline 1. & SMA Negeri 1 Jambi City & 41 & 15 \\
\hline 2. & SMA Negeri 3 Jambi City & 46 & 17 \\
\hline 3. & SMA Negeri 4 Jambi City & 39 & 14 \\
\hline 4 & SMA Negeri 5 Jambi City & 45 & 17 \\
\hline \multicolumn{2}{r}{ Total } & & 63 \\
\hline
\end{tabular}

By using this formula, the number of 63 respondents can be said to have 
representativeness.

Data collected from respondents were then processed using path analysis. Before carrying out statistical analysis, the data must meet requirements of the analysis prerequisites tests that would be used, namely tests of normality, linearity, homogeneity. After being analysed statistically, the results of data processing were discussed concerning theories or opinions that underlie this research to determine whether the results support the theory or not so that conclusions and recommendations can be made.

\section{RESULTS AND DISCUSSION Job Satisfaction Variable Data Description (Y)}

The number of questionnaires to explore data on Job Satisfaction (Y) was forty-four units with five indicators. Based on the findings of descriptive data with the guideline mean value (average) for this variable, it is concluded that the tendency of the level of Wage Adequacy is in the medium category. It has a mean value (2.98). Task Suitability is in the high category with a mean value (3.10). Opportunity to move forward is in the high category with a mean value (3.13). Then, the Partner indicator supports the medium category with a mean value (3.05). Happy indicators in the working atmosphere are in the medium category with a mean (3.04). Out of the five indicators, the average level of jobs satisfaction in the medium category is the mean value (3.06). Further data is illustrated in the diagram below:

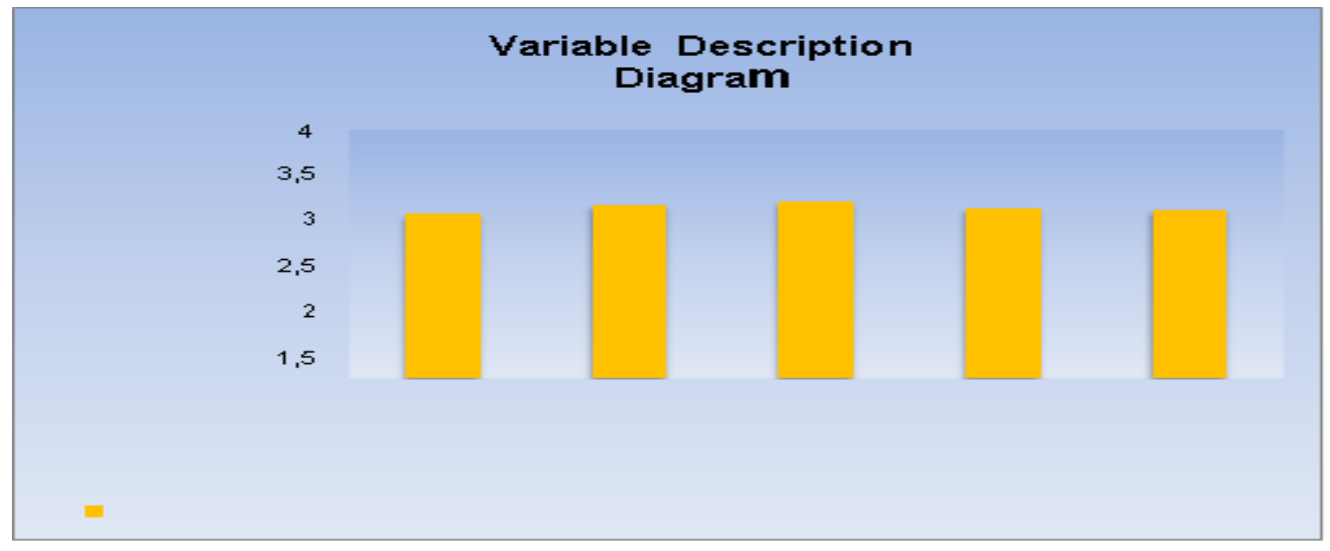

Picture 1. Job Satisfaction Description Diagram

\section{Work Climate Variable Data Description (X1)}

The number of questionnaires to explore data on Work Climate (X1) is forty units with five indicators. Based on the findings of descriptive data with the guidelines the mean value (average) for the Work Climate variable based on the data obtained shows that the tendency of the Decision level is in the medium Category with the mean value (3.071). Task Structure category is high with the mean value (3.181). Communication Flow is in high category with mean value (3.11). Then indicators Attention to workers is in high category with mean value (3.11). The Sportsmanship Indicator is in the medium category with a mean (3.08). So out of the five indicators, the average level of Work Climate is a High Category with a mean value (3.112). Further data is illustrated below: 


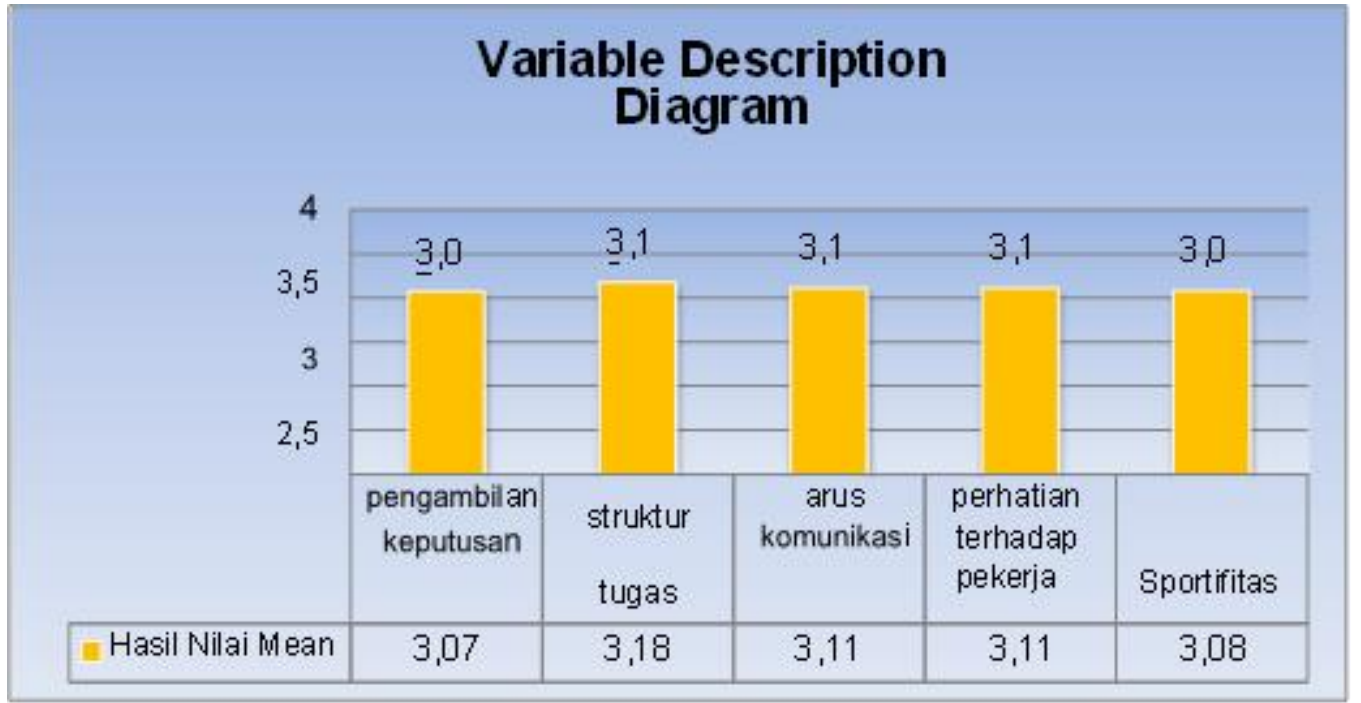

Picture 2. Work Climate Variable Description Diagram

\section{Description of the Variable Data on the Nature of Leadership (X2)}

The number of questionnaires to explore data about the nature of leadership (X2) is forty units with five indicators. Based on the findings of descriptive data with the guideline the mean value (average) for the Leadership Traits variable based on the data obtained shows that the tendency of the high category Personality level with the mean value (3.17). High category of Integrity with the mean value (3.10). High category of Confidence with mean value (3.14). Then, Social indicators are a medium category with mean value (3.07). Skill Indicators are in the high category with a mean (3.21) So out of the five indicators, the average level of leadership characteristics in the High Category is the mean value (3.14). Further data is illustrated in the diagram below:

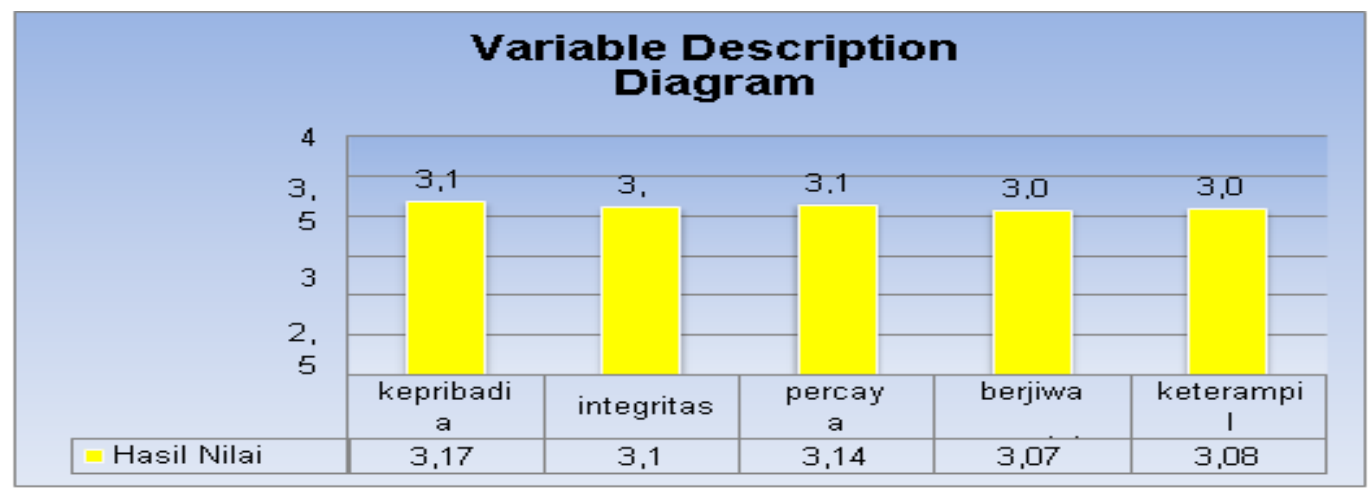

Picture 3. Description Diagram of Leadership Traits Variables

\section{Hypothesis Testing 1}

Table 3. Research Results and Hypothesis Testing (Regression Test)

\begin{tabular}{|c|c|c|c|c|}
\hline \multicolumn{5}{|c|}{ Model Summary ${ }^{b}$} \\
\hline Model & $\mathrm{R}$ & R Square & $\begin{array}{l}\text { Adjusted R } \\
\text { Square }\end{array}$ & $\begin{array}{l}\text { Std. Error of the } \\
\text { Estimate }\end{array}$ \\
\hline & $.350^{\mathrm{a}}$ & .122 & & 10.827 \\
\hline
\end{tabular}

a. Predictors: (Constant), Iklim Kerja

b. Dependent Variable: Work Satisfaction

The table above explains the value of correlation/relationship ( $R$ ) that is equal to 0.350 and explained the magnitude of the percentage of the influence of the Work Climate variable 
on Job Satisfaction obtained (R2) of 0.122. It implies that the influence of the Work Climate variable on Job Satisfaction is $12.2 \%$, while other variables influence the rest.

Table 4. F Test

\begin{tabular}{|c|c|c|c|c|c|}
\hline \multicolumn{6}{|c|}{ ANOVA $^{b}$} \\
\hline Model & Sum of Squares & df & Mean Square & $\mathbf{F}$ & Sig. \\
\hline Regression & 995.212 & 1 & 995.212 & 8.490 & $.005^{\mathrm{a}}$ \\
\hline Residual & 7150.438 & 61 & 117.220 & & \\
\hline Total & 8145.651 & 62 & & & \\
\hline
\end{tabular}

a. Predictors: (Constant), Work Climate

b. Dependent Variable: Work Satisfaction

From the output, it can be seen that the $\mathrm{F}$ count $=8.490$ with a significance level of $0.005<0.05$, then the regression model can be used to predict the Job Satisfaction variable.

Table 5. t Test

\begin{tabular}{|c|c|c|c|c|c|c|}
\hline \multicolumn{7}{|c|}{ Coefficients ${ }^{\mathbf{a}}$} \\
\hline \multirow{2}{*}{ Model } & & \multicolumn{2}{|c|}{ Unstandardised Coefficients } & $\begin{array}{r}\text { Standardised } \\
\text { Coefficients }\end{array}$ & \multirow[t]{2}{*}{$\mathrm{t}$} & \multirow[t]{2}{*}{ Sig. } \\
\hline & & $\mathrm{B}$ & Std. Error & Beta & & \\
\hline & (Constant) & 91.491 & 14.810 & & 6.178 & .000 \\
\hline & Iklim Kerja & .345 & .118 & .350 & 2.914 & .005 \\
\hline
\end{tabular}

Dependent Variable: Work Satisfaction

In the Coefficients table, Column B in Constant (a) 91,491, while the Work Climate value (b) is 0.345 so that the regression equation can be written:

$$
\mathrm{Y}=\mathrm{a}+\mathrm{bX} \text { or, } \mathrm{Y}=91,491+0,345 \mathrm{X}
$$

The coefficient $\mathrm{b}$ is called the regression direction coefficient and states the change in variable $\mathrm{X}$ by one unit. This change is an increase if $\mathrm{b}$ is positive and decreases if $\mathrm{b}$ is negative. So that from the equation can be translated:

1. A constant of 91,491 states that if there is no work climate value, then the value of job satisfaction is 91,491 .

2. The regression coefficient $X$ of 0.345 states that for each addition of 1 work climate value, the value of participation increases by 0.345 .

To find out whether there is a significant influence of the work climate variable (X1) (partial) on the job satisfaction variable $(\mathrm{Y})$, we can see that the $\mathrm{t}$ value $=2.914$ with a significance value of $0.005<0.05$. Then $\mathrm{H} 0$ is rejected, and $\mathrm{H} 1$ accepted, which means that there is a real (significant) influence of the work climate variable on the job satisfaction variable.

\section{Hypothesis Testing 2}

Table 6. Model Summary

\begin{tabular}{llcccc}
\hline Model & $\mathrm{R}$ & $\mathrm{R}$ Square & $\begin{array}{c}\text { Adjusted R } \\
\text { Square }\end{array}$ & \multicolumn{2}{c}{$\begin{array}{c}\text { Std. Error of the } \\
\text { Estimate }\end{array}$} \\
\hline 1 & $.321^{\mathrm{a}}$ & .103 & & .089 & 10.943 \\
\hline a. Predictors: (Constant), Sifat Kepemimpinan
\end{tabular}

The table above explains the magnitude of the correlation value/relationship $(\mathrm{R})$ that is equal to 0.321 and explains the magnitude of the percentage of the influence of the Leadership Traits variable on Job Satisfaction obtained (R2) of 0.103. It implies that the influence of the Leadership Trait on Work Satisfaction variable is equal to $10.3 \%$. In contrast, the rest is influenced by other variables. 


\begin{tabular}{|c|c|c|c|c|c|c|}
\hline \multicolumn{7}{|c|}{ ANOVA $^{b}$} \\
\hline \multirow{2}{*}{ Model } & & Sum of Squares & $\mathrm{df}$ & Mean Square & $\mathrm{F}$ & Sig. \\
\hline & Regression & 841.335 & 1 & 841.335 & 7.026 & $.010^{\mathrm{a}}$ \\
\hline & Residual & 7304.316 & 61 & 119.743 & & \\
\hline & Total & 8145.651 & 62 & & & \\
\hline
\end{tabular}

a. Predictors: (Constant), Leadership Traits

b. Dependent Variable: Work Satisfaction

From the output, it can be seen that $\mathrm{F}$ arithmetic $=7.026$ with a significance level of $0.01<0.05$, then the regression model can be used to predict Job Satisfaction variables.

\begin{tabular}{|c|c|c|c|c|c|}
\hline \multicolumn{6}{|c|}{ Coefficients $^{\mathbf{a}}$} \\
\hline \multirow[b]{2}{*}{ Model } & \multicolumn{2}{|c|}{$\begin{array}{c}\text { Unstandardised } \\
\text { Coefficients }\end{array}$} & \multirow{2}{*}{$\begin{array}{c}\begin{array}{r}\text { Standardised } \\
\text { Coefficients }\end{array} \\
\text { Beta } \\
\end{array}$} & \multirow[t]{2}{*}{$\mathrm{t}$} & \multirow[t]{2}{*}{ Sig. } \\
\hline & $\mathrm{B}$ & Std. Error & & & \\
\hline (Constant) & 101.258 & 12.601 & & 8.036 & .000 \\
\hline Sifat Kepemimpinan & .264 & .100 & .321 & 2.651 & .010 \\
\hline
\end{tabular}

Dependent Variable: Work Satisfaction

In the Coefficients table, Column B in Constant (a) 101,258, while the Leadership Trait (b) is 0.264 so that the regression equation can be written:

$$
\mathrm{Y}=\mathrm{a}+\mathrm{bX} \text { or, } \mathrm{Y}=101,258+0,264 \mathrm{X}
$$

The coefficient $\mathrm{b}$ is called the regression direction coefficient and states the change in variable $X$ by one unit. This change is an increase if $b$ is positive and decreases if $b$ is negative. So that from the equation can be translated:

1. A constant of 101,258 states that if there is no leadership trait value, then the value of job satisfaction is 101,258 .

2. The regression coefficient $X$ of 0.264 states that each addition of 1 value of leadership traits, the value of participation increases by 0.264 .

To find out whether there is a significant (significant) influence of the Leadership Character (X2) itself (partial) to the job satisfaction variable (Y), we can see that the value of $\mathrm{t}=2.651$ with a significance value of $0.01<0.05$. Then $\mathrm{H} 0$ is rejected, and $\mathrm{H} 1$ is accepted which implies there is a significant (significant) influence of the Leadership Traits variable on job satisfaction variables.

\section{Hypothesis Testing 3}

Model Summary

\begin{tabular}{ccccc}
\hline Model & $\mathrm{R}$ & R Square & $\begin{array}{c}\text { Adjusted R } \\
\text { Square }\end{array}$ & $\begin{array}{c}\text { Std. Error of the } \\
\text { Estimate }\end{array}$ \\
\hline $.379^{\mathrm{a}}$ & .144 & & .115 & 10.781 \\
\hline
\end{tabular}

Predictors: (Constant), Leadership Traits, Work Climate

The table above explains the value of correlation/relationship ( $\mathrm{R})$ that is equal to 0.379 and explained the magnitude of the percentage of the influence of the Work Climate and Leadership Traits variable on Job Satisfaction obtained (R2) of 0.144. It implies that the influence of the Work Climate variable and the Leadership Character Against Satisfaction Work is $14.4 \%$, while other variables influence the rest. 


\begin{tabular}{lcrrrr}
\multicolumn{8}{c}{ ANOVA $^{\mathbf{b}}$} & & \\
\hline Model & Sum of Squares & df & Mean Square & F & Sig. \\
\hline Regression & 1171.552 & 2 & 585.776 & 5.040 & .009a \\
\hline Residual & 6974.099 & 60 & 116.235 & & \\
\hline Total & 8145.651 & 62 & & & \\
\hline
\end{tabular}

a. Predictors: (Constant), Leadership Traits, Work Climate

b. Dependent Variable: Work Satisfaction

From the output, it can be seen that $\mathrm{F}$ arithmetic $=5,040$ with a significance level of $0.009<0.05$, it can be concluded that the hypothesis is accepted. It means the work climate variable and the nature of leadership have a significant effect on jointly on job satisfaction.

\begin{tabular}{|c|c|c|c|c|c|}
\hline \multicolumn{6}{|c|}{ Coefficients $\mathbf{a}^{\mathbf{a}}$} \\
\hline \multirow[t]{2}{*}{ Model } & $\begin{array}{l}\text { Unstandardised } \\
\text { Coefficients }\end{array}$ & & $\begin{array}{l}\text { Standardised } \\
\text { Coefficients }\end{array}$ & $\mathrm{t}$ & Sig. \\
\hline & $\mathrm{B}$ & Std. Error & Beta & & \\
\hline (Constant) & 85.626 & 15.497 & & 5.525 & .000 \\
\hline Iklim Kerja & .243 & .144 & .246 & 1.686 & .097 \\
\hline Sifat Kepemimpinan & .148 & .120 & .180 & 1.232 & .223 \\
\hline
\end{tabular}

The above output (coefficients) is used to describe the regression equation. From the above table it can be seen that $\mathrm{Y}=85,626+0,243 \mathrm{X} 1+0,148 \mathrm{X} 2$ or Teacher Job Satisfaction $=85,626+0,243$ (Working Climate) $+0,148$ (Trait of Leadership). The regression model with a sign (+) shows the direction of a direct relationship between variable $(\mathrm{X})$ and variable (Y).

\section{The Effect of Work Climate and the Nature of Leadership on Job Satisfaction}

The findings of the study used a questionnaire instrument to know the description of each variable and test the effect of Work Climate and the Nature of Leadership on Job Satisfaction of State High School Teachers in Jambi City. The results of the descriptive analysis of teacher job satisfaction are in the medium category, with a mean value of 3.065. Work climate shows a high category with a mean value of 3.112, and the Leadership Traits Variable shows a high category with a mean value of 3.143.

The result of simple regression analysis of the first hypothesis test shows that the work climate variable has a significant effect on job satisfaction, which is $12.2 \%$ with a significance level of 0.005 . If teacher job satisfaction reaches a percentage level of $100 \%$, then $12.2 \%$ is contributed by the work climate. The results can be interpreted that if teacher job satisfaction is classified as moderate (as stated in the previous descriptive findings), it is not only because of the contribution of teacher job satisfaction itself but also because of the role and work climate.

Job satisfaction is a positive emotional state of mind that determines the extent to which an individual feels his work-related needs are met (Demirtas, 2010; Evans, 1997). Teacher job satisfaction is a function of the perceived relationship between what one wants from one's work and regards teaching as offering or attracting. This is a product that results from the attitude and affective responses of teachers (Ho \& $\mathrm{Au}, 2006)$. Also, (Malinen \& Savolainen, 2016) describes teacher job satisfaction related to social and organisational factors (working conditions, relationships, autonomy), cognitive factors (collective efficacy, self-efficacy), and affective factors (fatigue, work stress).

Robbin (2005: 75) states that the factors that cause dissatisfaction are separate and 
different. They are different from those that produce job dissatisfaction. Therefore eliminating the factors that create job dissatisfaction can only produce harmony at work, but not motivation. Hygiene factors are extrinsic factors that eliminate work dissatisfaction but do not motivate. In contrast, motivators are intrinsic factors that increase job satisfaction and motivation.

The school work climate is considered an important research topic. However, there is no universal agreement on how it should be defined. Whereas a positive school climate can encourage teacher retention, which naturally increases student success (Bear, Yang, \& Pasipanodya, 2015). (van Houtte, 2005) defines the working climate in education as a means to describe the character of education management. In line with (Thapa, Cohen, Guffey, \& Higgins-D'Alessandro, 2013) School climate is based on the patterns of people's school life experiences. It reflects norms, goals, values, interpersonal relationships, teaching and learning practices, and organisational structure. (van Houtte, 2005) School climate is useful to describe the character of the school.

Idrus (2006: 105) states that the working climate influences whether or not the teacher is comfortable working in the school. Work comfort is the main requirement to create an atmosphere of employee job satisfaction, quality of work life. For this reason, increasing employee job satisfaction and quality of work-life can be achieved, one of which is by improving the work climate.

Several studies have sought to reveal the relevance of the influence of the work climate on teacher job satisfaction in schools that has an impact on student learning in the classroom. The study (Malinen \& Savolainen, 2016) found data collected from 642 Finnish secondary school teachers. The structural equation model revealed that the school climate has a positive effect, partly mediated by self-efficacy, on job satisfaction. A study by S. You, Kim, \& Lim (2017) finds that teachers with high job satisfaction have a positive influence on their students. So it is essential to understand teacher job satisfaction not only for teachers but also for students. (Ho \& Au, 2006) add that low teaching satisfaction correlates with work stress outcomes, namely psychological stress and low self-esteem. While (Pedro \& Peixoto, 2006) also stated that poor job satisfaction with teachers, affect not only themselves but also students. It is because of disinterest, and low teaching performance can directly contribute to the reduction of student interest and investment in the classroom and, consequently, to the deterioration in the quality of the learning process. Research by Sukkyung You, Kim, \& Lim (2017) found that school characteristics, perceptions of the academic climate, support from colleagues, and supportive primary leadership had a significant impact on teacher job satisfaction.

Other research is Rosnaniar. et., all (2013: 5) about the effect of organisational climate on the job satisfaction of implementing nurses in the inpatient hospital of Ince Abdul Moeis Samarinda Hospital. In this study, it was found that the organisational climate has a significant effect on job satisfaction.

The result of simple regression analysis of the second hypothesis test shows that the leadership trait variable has a significant effect on job satisfaction that is equal to $10.3 \%$ with a significance level of 0.009 . If teacher job satisfaction reaches a percentage level of $100 \%$, then $10.3 \%$ is contributed by the nature of leadership. The results can be interpreted that if teacher job satisfaction is classified as medium category (as stated in the previous descriptive findings), it is not only because of the contribution of teacher job satisfaction itself but also because of the influence of leadership traits on teacher job satisfaction.

Effective leadership and job satisfaction are two factors that have been considered as the basis for the success of a school. A leader who can provide direction for schools and teachers leads to the achievement of desired goals. In contrast, teachers with high job satisfaction tend to exert more effort in their duties in pursuing the interests of the school 
(Voon, et al. 2011: 23-32).

Firman (2016: 228) An effective leader is a leader who recognises the essential strengths that are in the individual. Every individual has different needs and desires. Each individual has a different level of expertise as well. Leaders must be flexible in understanding all the potential possessed by individuals and various problems faced by these individuals. By taking this approach, leaders can apply all the rules and policies of the organisation and delegate tasks and responsibilities appropriately. That idea is in line with efforts to foster work commitments from a teacher. So that the leader, in this case, the principal can later increase teacher job satisfaction with their work and can improve teacher performance more effectively.

Nir and Bogler (2008) explain that the higher the teacher's control over the professional development process of work, and the more similar these processes are to the distinctive teaching culture in the classroom, the greater the teacher's satisfaction with the professional development process of work. (Klassen \& Chiu, 2010) found that teachers who have a greater self-efficacious strategy have greater job satisfaction. (Ferguson, Frost, \& Hall, 2012) state that many years of teaching experience is a positive and positive predictor of job satisfaction.

The results of a simple regression analysis of the first hypothesis test showed that the variable work climate and leadership characteristics significantly influence job satisfaction. It is equal to $14.4 \%$ with a significance level of 0.009 . If teacher job satisfaction reaches a percentage level of $100 \%$, then $14.4 \%$ is contributed by the work climate and the nature of leadership. The results can be interpreted that if teacher job satisfaction is classified as medium category (as stated in the previous descriptive findings) it is not only because of the contribution of teacher job satisfaction itself, but also because of the role and works climate and the nature of leadership that affects teacher job satisfaction.

A pleasant work climate and the qualities of a leader gives the level of job satisfaction of teachers in school. The idea is because job satisfaction is a condition of liking or dislike according to the teacher's view of his work. Besides, job satisfaction is also an individual's feelings and reactions to the work environment. Therefore, the headmaster should be able to create a work environment that is conducive and has a useful leadership trait for the creation of job satisfaction of teachers in schools (Firman, 2016: 229).

To realise job satisfaction can be improved by improving the work climate and the characteristics of leaders so that it has an impact on teacher job satisfaction. A pleasant work climate and the qualities of a leader gives the level of job satisfaction of teachers in school. It is because job satisfaction is a condition of liking or dislike according to the teacher's view of his work. Besides, job satisfaction is also an individual's feelings and reactions to the work environment. Therefore, the headmaster should be able to create a work environment that is conducive and has an active leadership trait for the creation of job satisfaction of school teachers. Factors that influence the nature of the leader include personality, past experience and expectations of the leader, expectations and behaviour of superiors. Characteristics, expectations and behaviour of subordinates who show work motivation, task requirements, culture, wisdom and expectations and behaviour of colleagues also affect the nature of the leader. In turn, these factors influence the leader. Training and education can develop and assist leaders and teachers in meeting various components for increasing job satisfaction.

\section{CONCLUSION AND RECOMMENDATIONS}

\section{Conclusion}

From the results of the data processing done in the previous chapter, several research findings are produced with the following conclusions:

1. Work climate has a significant effect on job satisfaction in the amount of $12.2 \%$ with a significance level of 0.005 . If teacher job satisfaction reaches a percentage level of $100 \%$, 
then $12.2 \%$ is contributed by the work climate

2. The nature of leadership has a significant effect on job satisfaction in the amount of $10.3 \%$ with a significance level of 0.009 . If teacher job satisfaction reaches a percentage level of $100 \%$, then $10.3 \%$ is contributed by the nature of leadership.

3. Work climate, and the nature of leadership has a significant effect on job satisfaction in the amount of $14.4 \%$ with a significance level of 0.009 . If teacher job satisfaction reaches a percentage level of $100 \%$, then $14.4 \%$ is contributed by the work climate and the nature of leadership

\section{Recommendations}

Based on the research results that have been described, the researcher advises several parties who are considered capable of accommodating suggestions from researchers related to teacher job satisfaction, including:

1. To increase job satisfaction and maintain job satisfaction by creating a pleasant work climate to create togetherness and harmony to create an institutional synergetic relationship.

2. The nature of leadership needs to be considered in efforts to increase teacher job satisfaction by involving teachers in making decisions related to teaching and learning activities and maintaining good leadership through assignments that are proportional to the professionalism of teachers, implementing attitudes of transparency and accountability, especially those related to policies.

\section{REFERENCES}

Abdul Raziq, dan Raheela Maulabakhsh. (2015). Impact of Working Environment on Job Satisfaction (Pakistan: Procedia Economics and Finance.

Djoerban Wahid. (2007). Efektivitas Kerja: Kaidah Perilaku. Jakarta: Erlangga.

Fred Luthans. (2006). Organisational Behavior, 10 ${ }^{\text {th }}$ Edition. New York: McGraw-Hil. Ganesh Salunke. (2015). Work Environment And Its Effect On Job Satisfaction In

Cooperative Sugar Factories In Maharashtra, India (India: Abhinav International Monthly Refereed Journal of Research in Management \& Technology, Volume 4/5.

Gary Yukl. (2007). Kepemimpin dalam Organisasi. Edisi ke 5. Jakarta: Indeks.

Husain Usman. (2011). Manajemen, Teori,Praktik, dan Riset Pendidikan Edisi 3. Jakarta: Bumi Aksara.

Norazah Mohd Suki. (2011). Job Satisfaction And Organisational Commitment: The Effect of Gender. (Malaysia: International Journal of Psychology Research. Volume 6/5.

Peter G, Northouse. (2013). Kepemimpinan, teori dan Praktik. Edisi Keenam, terjemahan Ati Cahyani. Jakarta: Indeks.

Riduwan., Kuncoro, E.A. (2013). Cara Menggunakan dan Memaknai Path Analysis. Bandung: Alfabeta.

Robbin. (2005). Prinsip-prinsip Prilaku Organisasi. Jakarta: Erlangga

Rosnaniar et.all. (2013). Pengaruh Iklim Organisasi Terhadap Kepuasan Kerja Perawat Pelaksana Diruang Rawat Inap RSUD Ince Abdul Moeis Samarinda.

Siti Zawiah Md. Dawal \& Zahari Taha. (2015). The Effect of Job and Environmental Factors on Job Satisfaction in Automotive Industries. International Journal of Occupational Safety and Ergonomics. Vol. 12, No. 3.

Stephen P Robbins. (2006). Perilaku Organisasi. Jakarta, Indeks Sugiyono. (2009). Metode Penelitian Bisnis. Bandung:Alfabeta.

Veithzal Rivai \& Ella Jauvani Sagala. (2013). Manajemen Sumber Daya Manusia untuk Perusahaan (Jakarta: Raja Grafindo

Veithzal Rivai \& Deddy Mulyadi. (2013). Kepemimpinan dan Perlaku Organisasi Jakarta: Rajawali Pres. 
Voon, et. All. (2011). The Influence of Leadership Styles on Employees' Job Satisfaction in Public Sector Organizations In Malaysia. International Journal of Business, Management and Social Sciences Vol. 2, No. 1, 2011, pp. 24-32. 